\title{
Stimulation of 14-3-3 Protein and Its Isoform on Histamine Secretion from Permeabilized Rat Peritoneal Mast Cells
}

\author{
Toshihiro FuJII* and Takayuki UEEDA \\ Department of Kansei Engineering, Faculty of Textile Science and Technology, Shinshu University; Ueda, Nagano \\ 386-8567, Japan. Received May 20, 2002; accepted August 8, 2002
}

The effect of the 14-3-3 protein, an adaptor protein of intracellular signal pathways, on histamine release from rat peritoneal mast cells was investigated. The exogenous 14-3-3 protein from bovine brain increased the $\mathrm{Ca}^{2+}$-dependent histamine release from permeabilized mast cells, but only slightly affected the non-permeabilized cells. Partial amino acid sequences showed that the bovine brain 14-3-3 protein contained 14-3-3 $\beta, \gamma$ and $\zeta$ isoforms, and that these recombinant isoforms were prepared. Among them, 14-3-3 $\zeta$ was an active species while the 14-3-3 $\beta$ and $\gamma$ were inactive for histamine release from the permeabilized mast cells. Approximately $15 \%$ of the histamine release was stimulated by 14-3-3 $\zeta$ at $2.5 \mu \mathrm{M}$, and half-maximal stimulation occurred at $1 \mu \mathrm{M}$. Treatment of the mast cells with wortmannin or staurosporine completely inhibited the stimulatory effect on histamine release caused by $\mathrm{Ca}^{2+}$ or $\mathrm{Ca}^{2+} / 14-3-3 \zeta$, and genistein partially inhibited both stimulatory effects. PD 98059, however, had little effect on the histamine release. These results suggest the possibility that 14-3-3 $\zeta$ is associated with signal transduction for degranulation of the mast cells.

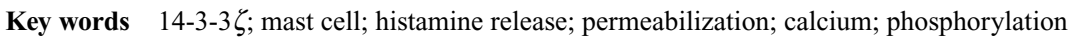

The 14-3-3 protein is a family of conserved, dimeric proteins with a monomeric molecular mass of about $30 \mathrm{kDa}$, and is ubiquitously expressed in various mammalian tissues. ${ }^{1,2)}$ At least nine isoforms, including $\alpha, \beta, \gamma, \varepsilon, \zeta, \tau, \sigma, \delta$ and $\eta$, are known, and the isoforms of $\alpha$ and $\delta$ are phosphorylated forms of $\beta$ and $\zeta$, respectively. The 14-3-3 protein has been reported to regulate numerous cellular processes, including signal transduction, exocytosis, cell cycle and apotosis by interaction with a variety of regulatory proteins controlling signal pathways. The target proteins include tyrosine and tryptophan hydroxylases, ${ }^{3,4)}$ protein kinase $C^{5,6)}$ Raf-1, ${ }^{7)}$ phosphatidylinositol 3-kinase (PI3-kinase), ${ }^{8)} \mathrm{Cdc} 25$ phosphatase $\left.{ }^{9}\right)$ and a Bcl-2 family, Bad. ${ }^{10)}$

Mast cells and blood basophils release histamine and other potent inflammatory mediators in response to the cross-linking of $\mathrm{IgE}$ receptors under acute allergic and inflammatory conditions. $^{11,12)}$ It is also generally believed that calcium and phosphorylation signalings are closely associated with the exocytosis of mast cells. The function of protein kinase $\mathrm{C}$ and $\mathrm{Ca}^{2+}$ /calmodulin on the secretory process of mast cells has been examined in detail. ${ }^{13,14)}$ Burgoyne and co-workers reported that 14-3-3 protein stimulated catecholamine release from digitonin-permeabilized adrenal chromaffin cells in a $\mathrm{Ca}^{2+}$-dependent manner. ${ }^{15-17)}$ However, little is known about the effect of 14-3-3 protein on the secretion of mast cells. The use of permeabilized cells has provided a means of identification of soluble proteins and signal transmission pathways that are related to the exocytotic process. Previously, we reported that the smooth muscle calcium-binding protein 11 (calcyclin) prevented $\mathrm{Ca}^{2+}$-dependent histamine release from permeabilized rat peritoneal mast cells. ${ }^{18)}$

In this paper, we report that exogenous 14-3-3 protein can stimulate $\mathrm{Ca}^{2+}$-dependent histamine release from permeabilized mast cells. Among the isoforms of 14-3-3 protein, 143-3 $\zeta$ was an active species, and its enhancement was completely inhibited by staurosporine and wortmannin.

\section{MATERIALS AND METHODS}

Materials Staurosporine and ionophore A23187 were purchased from Sigma. Genistein, wortmannin, PD 98059 and peroxidase-conjugated goat anti-rabbit IgG+IgM immunoglobulins were purchased from Wako Pure Chemical Industry.

Preparation of 14-3-3 Protein The bovine brain 14-3-3 protein was prepared by the method of Morgan and Burgoyne $^{15)}$ with slight modification. Fresh tissues $(200 \mathrm{~g})$ were homogenized in 2 volumes of $20 \mathrm{~mm}$ piperazine- $N, N^{\prime}$-bis(2ethanesulfonic acid, $\mathrm{pH} 6.5,139 \mathrm{~mm}$ potassium glutamate, $5 \mathrm{~mm} \mathrm{MgCl}_{2}, 2 \mathrm{~mm}$ EGTA, 2 mм 2-mercaptoethanol (2-ME) and $2 \mathrm{~mm}$ ATP using a Waring blender. The suspension was centrifuged at $4000 \times \boldsymbol{g}$ for $5 \mathrm{~min}$ at $4{ }^{\circ} \mathrm{C}$. The obtained supernatants were dialyzed against buffer A (10 mM imidazole$\mathrm{HCl}, \mathrm{pH}$ 7.3, $1 \mathrm{~mm}$ 2-ME, $1 \mathrm{~mm} \mathrm{NaN}_{3}$ and $1 \mathrm{~mm}$ EGTA) and loaded onto a DEAE-Sepharose column $(\phi 3.5 \times 11 \mathrm{~cm})$ equilibrated with buffer $A$. Fractions containing the 14-3-3 protein were collected, dialyzed against buffer $\mathrm{A}+1 \mathrm{M}\left(\mathrm{NH}_{4}\right)_{2} \mathrm{SO}_{4}$ and loaded onto a phenyl-Sepharose $4 \mathrm{~B}$ column $(\phi 1.5 \times 15$ $\mathrm{cm})$ equilibrated with buffer $\mathrm{A}+1 \mathrm{M}\left(\mathrm{NH}_{4}\right)_{2} \mathrm{SO}_{4}$. The column was washed with the same buffer, and the bound protein was eluted with a linear $1-0 \mathrm{M}\left(\mathrm{NH}_{4}\right)_{2} \mathrm{SO}_{4}$ gradient. The eluted 14-3-3 protein-rich fractions were then collected and dialyzed against buffer $\mathrm{A}$. The sample was applied to a QMA (Waters) column equilibrated with buffer $\mathrm{A}$ and then eluted with a linear $0-600 \mathrm{~mm} \mathrm{NaCl}$ gradient. The 14-3-3 fractions were collected, dialyzed against buffer $\mathrm{A}+1 \mathrm{M}\left(\mathrm{NH}_{4}\right)_{2} \mathrm{SO}_{4}$ and re-loaded onto a phenyl-Sepharose $4 \mathrm{~B}$ column $(\phi 0.8 \times 3$ $\mathrm{cm})$ equilibrated with buffer $\mathrm{A}+1 \mathrm{M}\left(\mathrm{NH}_{4}\right)_{2} \mathrm{SO}_{4}$. The column was washed with the same buffer, and the bound protein was eluted with a linear $1-0 \mathrm{M}\left(\mathrm{NH}_{4}\right)_{2} \mathrm{SO}_{4}$ gradient. The eluted 14-3-3 fraction was concentrated and applied to an AcA-54 column $(\phi 3 \times 85 \mathrm{~cm})$ equilibrated with buffer A containing $100 \mathrm{~mm} \mathrm{NaCl}$. The 14-3-3 protein was then collected and stored at $-80^{\circ} \mathrm{C}$. The yield of purified 14-3-3 protein was about $1 \mathrm{mg}$ per $100 \mathrm{~g}$ of tissues.

The full-length cDNAs of 14-3-3 $\beta, \gamma$ and $\zeta$ were cloned 
by reverse transcriptase-polymerase chain reaction (RTPCR). The total RNA was extracted from the adult rat brain (Wistar) with ISOGEN containing phenol and guanidine isothiocyanate (Nippon Gene $\mathrm{KK}$ ) according to the manufacturer's protocol. The sense primers of $14-3-3 \beta, \gamma$ and $\zeta$, including the Nde I restriction site, are 5 '-AAAGAACCATATGACCATGGACAAA-AGTGA-3', 5'-TTAATTAACATATGGTGGACCGCGAGCAAC-3' and 5'-TAGAAATCATATGGATAAAAATGAGCTGG-T-3', respectively. The antisense primers of 14-3-3 $\beta, \gamma$ and $\zeta$, including the EcoR I restriction site, are 5'-GGCGAATTCAAAGATCGAAAGTCCACAT3',5' -AAAAGAATTCTGTGAGGCTGCTACTCCGAT-3' and 5'-ATTGAATTCAACAAAAAAACTATCTGTGGG-3', respectively. The double-stranded cDNAs amplified by RTPCR $\left(30\right.$ cycles at $94{ }^{\circ} \mathrm{C}$ for $1 \mathrm{~min}, 55^{\circ} \mathrm{C}$ for $1 \mathrm{~min}$ and $72^{\circ} \mathrm{C}$ for $1 \mathrm{~min}$ ) were inserted into the pAED4 plasmid vector and transformed into E. coli (JM109) for amplification. ${ }^{19)}$ The recombinant DNAs of pAED4-14-3-3 $\beta, \gamma$ and $\zeta$ were transformed into the $E$. coli host strain BL21 (DE3) and identified by restriction analysis. Each recombinant 14-3-3 isoform was expressed in BL21 (DE3) that was cultured at $37^{\circ} \mathrm{C}$ in $\mathrm{LB}$ medium containing $0.5 \mathrm{mg} / \mathrm{ml}$ ampicillin. After adding isopropyl-1-thio- $\beta$-D-galactopyranoside to a final concentration of $0.1 \mathrm{~mm}$, the cells were incubated for another $4 \mathrm{~h}$. Cells were suspended in buffer A and subjected to disruption with a sonicater ( $30 \mathrm{~s} \times 30$ times). Each 14-3-3 isoform was purified by the previously described method.

Preparation of Mast Cells, Cell Permeabilization and Histamine Release Mast cells were obtained from the abdominal cavities of male rat (Wistar; 300-400 g), as described previously. ${ }^{18)}$ The content of the mast cells in the preparation examined by toluidine blue staining was greater than $95 \%$. The freshly isolated mast cells were suspended at a density of $5 \times 10^{5} \mathrm{ml}^{-1}$ in mast cell medium (MCM), which was comprised of $144 \mathrm{~mm} \mathrm{NaCl}, 2.7 \mathrm{~mm} \mathrm{KCl}, 4.7 \mathrm{~mm}$ $\mathrm{Na}_{2} \mathrm{HPO}_{4}, 2 \mathrm{~mm} \mathrm{KH}_{2} \mathrm{PO}_{4}, 5.6 \mathrm{~mm}$ glucose, $10 \mathrm{U} / \mathrm{ml}$ heparin and $1 \mathrm{mg} / \mathrm{ml}$ bovine serum albumin ( $\mathrm{pH} \mathrm{7})$, and then used for each experiment. The purified mast cells $\left(2 \times 10^{4} /\right.$ tube $)$ containing 14-3-3 protein were preincubated in $200 \mu \mathrm{l}$ of MCM for $5 \mathrm{~min}$ at $37^{\circ} \mathrm{C}$ and permeabilized by the addition of $12.5 \mu \mathrm{g} / \mathrm{ml} \beta$-escin for $10 \mathrm{~min}$ at $37^{\circ} \mathrm{C}$. The cell suspension was further incubated for $10 \mathrm{~min}$ at $37^{\circ} \mathrm{C}$ after adding $0.9 \mathrm{mM} \mathrm{CaCl}_{2}$. The reactions were stopped by adding $1.8 \mathrm{ml}$ of ice-cold MCM containing $1 \mathrm{~mm}$ EGTA. The mast cells were pelleted, and the histamine released into the medium was assayed using $o$-phthalaldehyde as described by Shore et $a l .{ }^{20)}$ Histamine release from the mast cells (\%) was calculated by the following equation: [(histamine release)-(spontaneous release $)] /($ total histamine $)-($ spontaneous release $)] \times$ 100.

Sodium Dodecyl Sulfate-Polyacrylamide Gel Electrophoresis (SDS-PAGE) and Immunoblotting Aliquots of the mast cell lysate and 14-3-3 protein were mixed with concentrated SDS-PAGE sample buffer, then boiled and subjected to SDS-PAGE on $12.5 \%$ polyacrylamide gels using the Laemmli buffer system. ${ }^{21}$ Proteins were electrotransferred onto a nitrocellulose membrane (Advantec) in a $25 \mathrm{~mm}$ Tris, $192 \mathrm{~mm}$ glycine and $20 \%$ methanol mixture at $100 \mathrm{~V}$ for $1 \mathrm{~h}$. The transferred membrane was blocked with $2.5 \%$ TBS (25 mM Tris- $\mathrm{HCl}, \mathrm{pH} 7.2,50 \mathrm{~mm} \mathrm{NaCl}$ ) and immunoblotted with $1: 1500$ polyclonal antibodies to porcine $14-3-3$ protein for $90 \mathrm{~min}$ at $37^{\circ} \mathrm{C}$. The membrane was washed 4 times with TBS-T (TBS containing 0.5\% Tween-20) and then immunoblotted with $1: 30000$ peroxidase-conjugated secondary antibodies, goat anti-rabbit IgG (H and L) antibody in TBS-T for $90 \mathrm{~min}$ at $37^{\circ} \mathrm{C}$. Detection was performed using the Super Signal CL-HRP Substrate System (Pierce). ${ }^{22)}$

Amino Acid Sequencing For amino acid sequencing, the 14-3-3 protein and its digest were applied onto SDSPAGE. Proteins on the gel were electroblotted onto a polyvinylidene difluoride (PVDF) membrane. After Ponceau $\mathrm{S}$ staining, the proteins on the PVDF membranes were directly applied to a Shimadzu PPSQ-21 Protein Sequencer.

Statistical Analysis Data are expressed as mean \pm S.E.M. Student's two-sided $t$-test was used to examine the significance of difference among groups.

\section{RESULTS AND DISCUSSION}

Histamine Release by 14-3-3 Protein Treatment of rat peritoneal mast cells with $12.5 \mu \mathrm{g} / \mathrm{ml} \beta$-escin in the presence of $0.9 \mathrm{mM} \mathrm{CaCl}_{2}$ caused histamine release (about $10 \%$ ) which compared with the amount in the absence of $\mathrm{CaCl}_{2}$ (Fig. 1). When bovine brain 14-3-3 protein was incubated with the permeabilized mast cells, the histamine release increased with increasing amounts of protein added in the presence of $\mathrm{Ca}^{2+}$, but not in the presence of EGTA. Furthermore, we observed that 14-3-3 protein had little influence on non-permeabilized cells which were stimulated by the $\mathrm{Ca}^{2+}$ plus ionophore A23187, indicating that the 14-3-3 protein functions after incorporation into the mast cells. The stimulation of $\mathrm{Ca}^{2+}$-dependent histamine release reached about 2-2.5fold of the original level in the absence of 14-3-3 protein at more than $2.5 \mu \mathrm{M}$, and half-maximal stimulation was $0.8-$ $1.2 \mu \mathrm{M}$.

Analysis of 14-3-3 Isoforms and Preparation of 14-3$\mathbf{3} \boldsymbol{\beta}, \boldsymbol{\gamma}$ and $\boldsymbol{\zeta}$ The 14-3-3 protein has been reported to consist of a number of isoforms, including $\beta, \gamma, \varepsilon, \zeta, \eta, \theta$ and $\sigma$. We examined which of these isoforms are contained in the bovine brain 14-3-3 protein fraction. Since the $\mathrm{N}$ terminal

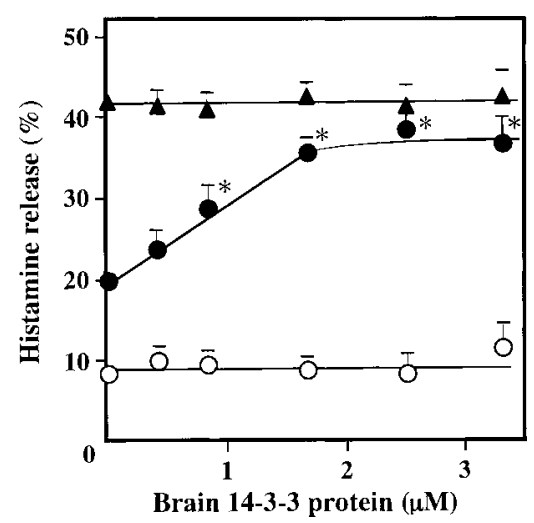

Fig. 1. Histamine Release from Permeabilized Mast Cells by Brain 14-3-3 Protein

Mast cells were preincubated with various concentrations of 14-3-3 protein, as indicated, for $5 \mathrm{~min}$ at $37^{\circ} \mathrm{C}$. The cells were permeabilized with $12.5 \mu \mathrm{g} / \mathrm{ml} \beta$-escin for $10 \mathrm{~min}$ at $37^{\circ} \mathrm{C}$, and then challenged with $0.9 \mathrm{~mm} \mathrm{CaCl}_{2}(\bullet)$ or $0.5 \mathrm{~mm}$ EGTA (O) for $10 \mathrm{~min}$. The cells were also stimulated by $0.4 \mu \mathrm{g} / \mathrm{ml}$ ionophore $\mathrm{A} 23187+0.9 \mathrm{mM} \mathrm{CaCl}_{2}$ $(\boldsymbol{\Delta})$ at for $10 \mathrm{~min} 37^{\circ} \mathrm{C}$. Values are expressed as means \pm S.E. of three or four experiments done in duplicate. The molecular weight of the 14-3-3 protein was calculated to be $60000 . * p<0.05$ versus control. 


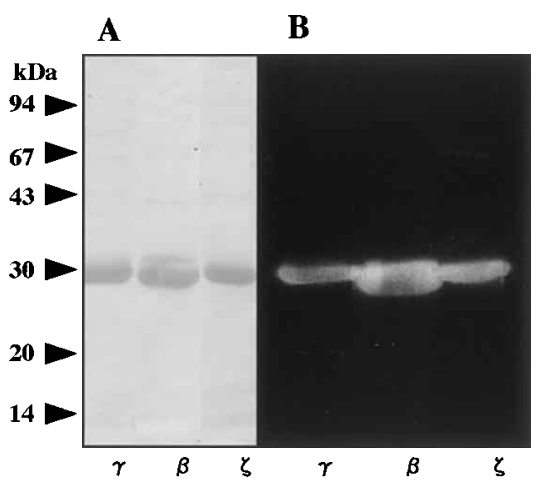

Fig. 2. Western Blot Analysis of Recombinant 14-3-3 Isoforms Using Antibodies against Porcine 14-3-3 Protein

The purified recombinant $14-3-3 \beta, \gamma$ and $\zeta$ were separated by $12.5 \%$ SDS-PAGE. Proteins were electrophoretically transferred from the gel to a nitrocellulose membrane, then stained with amide black (A) or immunostained with anti-porcine brain 14-3-3 protein antibodies (B). Lane 1, 14-3-3 $\beta$; lane 2, 14-3-3 $\gamma$; lane 3, 14-3-3 $\zeta$. Molecular weight standards in $\mathrm{kDa}$ are shown on the left.

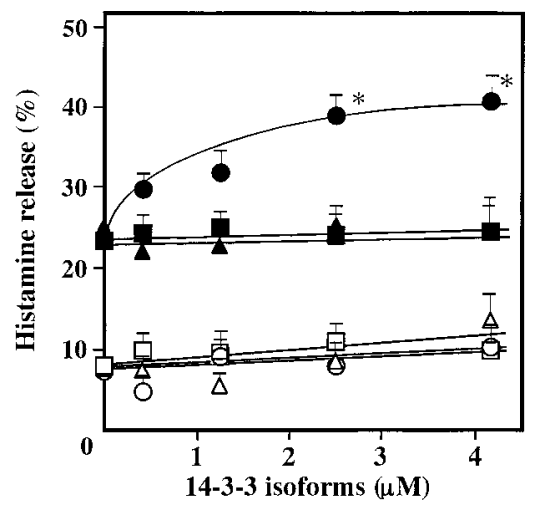

Fig. 3. Effects of 14-3-3 Isoforms on Histamine Release from Permeabilized Mast Cells in the Presence and Absence of $\mathrm{CaCl}_{2}$

Mast cells were preincubated with the recombinant 14-3-3 $\beta(\triangle, \boldsymbol{\Delta}), \gamma(\square, \boldsymbol{\square})$ and $\zeta$ $(\mathrm{O}, \boldsymbol{\bullet})$ for $5 \mathrm{~min}$ at $37^{\circ} \mathrm{C}$. The cells were further permeabilized with $12.5 \mu \mathrm{g} / \mathrm{ml} \beta$ escin and challenged with $0.9 \mathrm{~mm} \mathrm{CaCl}_{2}(\boldsymbol{\bullet}, \boldsymbol{\Delta}, \boldsymbol{\square})$ or $1 \mathrm{~mm}$ EGTA $(\bigcirc, \triangle, \square)$, as shown in the legend of Fig. 1. Values are expressed as means \pm S.E. of three or four experiments done in duplicate. $* p<0.05$ versus control.

amino acid of the bovine brain 14-3-3 protein was blocked, its fragment with a $25 \mathrm{kDa}$ fragment generated by chymotryptic limited digestion was used for analyzing the partial amino acid sequence by Edman degradation. The $25 \mathrm{kDa}$ fragment begins at R-V-(I, V)-S-S-I-E-Q-K-T-(E, M, D, S)$(A, G, R, N)-(A, D, N, S)-(E, G)-(K, N)-(K, E)-(K, Q)-(K, Q)-$ $(\mathrm{M}, \mathrm{L}, \mathrm{I})-(\mathrm{E}, \mathrm{A}) \ldots$, which corresponds to the $\alpha$-helix domain from $\operatorname{Arg} 60-62$, as the reported amino acid sequence of 14-3$3 \beta, \gamma$ and $\zeta$ isoforms. ${ }^{4,23)}$ These data suggest that $14-3-3 \beta, \gamma$ and $\zeta$ isoforms, at least, may be members of the bovine brain 4-3-3 protein. Next, we prepared recombinant $14-3-3 \beta, \gamma$ and $\zeta$ as described in "Materials and Methods". Immunoblot analysis shows that the three recombinant proteins are crossreacted with antibodies against porcine brain 14-3-3 protein (Fig. 2). Furthermore, partial amino acid sequence analysis (till 15 amino acids) indicates that each protein is identical to the reported amino acid sequence. ${ }^{23)}$ We used these proteins in the following experiments.

Effect of 14-3-3 Isoforms on Histamine Release from Permeabilized Mast Cells The histamine release from permeabilized mast cells was examined by adding exogenous 14-3-3 isoforms (Fig. 3). Interestingly, 14-3-3 $\zeta$ showed a

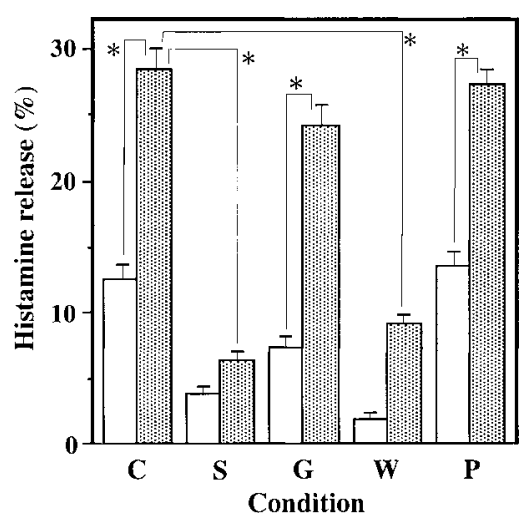

Fig. 4. Effect of Kinase Inhibitors on $\mathrm{Ca}^{2+}$ - and 14-3-3 $\zeta$-dependent Histamine Release from Permeabilized Mast Cells

Mast cells were preincubated with $14-3-3 \zeta(2.5 \mu \mathrm{M})$ and the indicated drugs $(50 \mu \mathrm{M})$ for $5 \mathrm{~min}$ at $37^{\circ} \mathrm{C}$ in the presence of $0.9 \mathrm{mM} \mathrm{CaCl}_{2}$. The cells were permeabilized with $12.5 \mu \mathrm{g} / \mathrm{ml} \beta$-escin and challenged with $0.9 \mathrm{mM} \mathrm{CaCl}_{2}$, as shown in the legend of Fig. 1 . $0.9 \mathrm{mM} \mathrm{CaCl}_{2}$; $0.9 \mathrm{~mm} \mathrm{CaCl}+2.5 \mu \mathrm{M}$ 14-3-3 $\zeta$. C, control; S, staurosporine; G, genistein; W, wortmannin; P, PD 98059. Values are expressed as means \pm S.E. of three experiments done in duplicate. $* p<0.05$ versus controls.

stimulatory effect on histamine release in the presence of $\mathrm{CaCl}_{2}$, but not in the presence of EGTA. On the other hand, both $14-3-3 \beta$ and $\gamma$ had little effect on histamine release in the presence and absence of $\mathrm{CaCl}_{2}$. The maximal release by $14-3-3 \zeta$ reached about $40 \%$ (substantial amount of $32 \%$ ) of the total histamine content in the mast cells, and half-maximal release occurred at $1 \mu \mathrm{m}$. These values were in good accord with those obtained by brain 14-3-3 protein, as shown in Fig. 1. We postulated that bovine the brain 14-3-3 protein used was a mixture of homo- and hetero-dimeric molecules, while the recombinant 14-3-3 isoforms are individual homodimers. These may affect the different actions on the secretory processes in mast cells.

Effect of Drugs on 14-3-3 $\zeta$-dependent Histamine Release The interactions of 14-3-3 protein with Raf-1, c-Bcr, $\mathrm{Cb} 1$, tyrosine hydroxylase and tryptophan hydroxylase were regulated by phosphorylation and dephosphorylation. ${ }^{2,23,24)}$ Aitken et al. ${ }^{25)}$ have shown that phosphorylated $14-3-3 \zeta$, as well as 14-3-3 $\beta$, exhibits increased potency in the inhibition of the protein kinase $\mathrm{C}$ activity. It is also interesting to note that recombinant $14-3-3 \zeta$ is essential for exhibiting Raf kinase activity, and Raf kinase is certainly present in the mast cells. $^{24,26)}$

To determine whether phosphorylation and dephosphorylation were involved in the stimulatory release of histamine by $14-3-3 \zeta$, mast cells were preincubated with or without kinase inhibitors, such as staurosporine (for serine/threonine kinases), genistein (for tyrosine kinases), wortmannin (for PI3-kinase) and PD 98059 (for mitogen-activated protein kinase kinase) for $5 \mathrm{~min}$ at $37^{\circ} \mathrm{C}$. After permeabilization by adding $\beta$-escin, the mast cells were further incubated in the presence of $\mathrm{CaCl}_{2}$ for $10 \mathrm{~min}$ at $37^{\circ} \mathrm{C}$. The $\mathrm{Ca}^{2+}$-dependent histamine release from permeabilized mast cells was suppressed by staurosporine $(50 \mu \mathrm{M})$ and wortmannin $(50 \mu \mathrm{M})$. Furthermore, the stimulatory histamine release by $14-3-3 \zeta$ was completely decreased to the original level in the absence of 14-3-3 $\zeta$, when staurosporine or wortmannin was present. The action of $14-3-3 \zeta$ is thus phosphorylation-dependent. Furthermore, 14-3-3 protein has been reported to directly interact with PI3 kinase and inhibits activity in T cells. ${ }^{27)}$ The 
addition of genistein, which partially inhibits histamine release induced by $\mathrm{Ca}^{2+}$, did not affect $\mathrm{Ca}^{2+}$ plus $14-3-3 \zeta$-dependent histamine release. PD 98059 had little effect on both histamine releasing conditions. These results suggest that $14-$ 3-3 $\zeta$ affects the PI3 kinase related signal transduction pathways other than the mitogen-activated protein kinase pathways, and leads to histamine release at higher intracellular $\mathrm{Ca}^{2+}$ concentrations.

Acknowledgments We thank Dr. C. Itagaki (Department of Biochemistry, Faculty of Science, Niigata University) for providing the anti-14-3-3 polyclonal antibodies. We also wish to thank Drs. M. Okazaki and G. Taguchi (Gene Research Center, Shinshu University) for helpful suggestions and discussion related to this work. This study was supported by Hokuto Foundation for Bioscience and Grants-in-Aid for COE Research (H10CE2003) and Science Research (C) (14593003) from the Ministry of Education, Culture, Sports, Science and Technology of Japan.

\section{REFERENCES}

1) Fu H., Subramanian R. R., Masters S. C., Annu. Rev. Pharmacol. Toxicol., 40, 617-647 (2000).

2) Tzivion G., Avruch J., J. Biol. Chem., 277, 3061-3064 (2002).

3) Ichimura T., Isobe T., Okuyama T., Yamauchi T., Fujisawa H., FEBS Lett., 219, 79-82 (1987).

4) Ichimura T., Isobe T., Okuyama T., Takahashi N., Araki K., Kuwano R., Takahashi Y., Proc. Natl. Acad. Sci. U.S.A., 85, 7084-7088 (1988).

5) Toker A., Ellis C. A., Sellers L. A., Aitken A., Eur. J. Biochem., 191, $421-429$ (1990).

6) Furukawa Y., Ikuta N., Omata S., Yamauchi T., Isobe T., Ichimura T., Biochem. Biophys. Res. Commun., 194, 144-149 (1993).
7) Fu H., Xia K., Pallas D. C., Cui C., Conroy K., Narsimhan R. P., Mamon H., Collier R. J., Roberts T. M., Science, 266, 126-129 (1994).

8) Bonnefoy-Berard N., Liu Y. C., von Willebrand M., Sung A., Elly C., Mustelin T., Yoshida H., Ishizaka K., Altman A., Proc. Natl. Acad. Sci. U.S.A., 92, 10142-10146 (1995).

9) Conklin D. S., Galaktionov K., Beach D., Proc. Natl. Acad. Sci. U.S.A., 92, 7892-7896 (1995).

10) Zha J., Harada H., Yang E., Jockel J., Korsmeyer S. J., Cell, 87, 619628 (1996).

11) Grant J. A., Dupree E., Goldman A. S., Schultz D. R., Jackson A. L., J. Immunol., 114, 1101-1106 (1975).

12) Ishizaka T., Ishizaka K., Prog. Allergy, 34, 188-235 (1984).

13) Izushi K., Tasaka K., Pharmacology, 44, 61-70 (1992).

14) Razin E., Szallasi Z., Kazanietz M. G., Blumberg P. M., Rivera J., Proc. Natl. Acad. Sci. U.S.A., 91, $7722-7726$ (1994).

15) Morgan A., Burgoyne R. D., Nature (London), 355, 833-836 (1992).

16) Roth D., Morgan A., Burgoyne R. D., FEBS Lett., 320, 207-210 (1993).

17) Roth D., Burgoyne R. D., FEBS Lett., 374, 77-81 (1995).

18) Fujii T., Kuzumaki N., Ogoma Y., Kondo Y., Biol. Pharm. Bull., 17, $581-585$ (1994).

19) Fujii T., Nakamura K., Ootani H., Koizumi Y., Takahashi K., J. Biochem. Mol. Biol. \& Biophys., 5, 399-405 (2001).

20) Shore P. A., Burkhalter A., Cohn V. H., J. Pharmacol. Exp. Ther, 127, 182-186 (1959).

21) Laemmli U. K., Nature (London), 227, 680-685 (1970).

22) Nakamura A., Arimoto M., Fujii T., Biol. Pharm. Bull., 25, 569-572 (2002).

23) Isobe T., Hiyane Y., Ichimura T., Okuyama T., Takahashi N., Nakajo S., Nakaya K., FEBS Lett., 308, 121-124 (1992).

24) Aitken A., Howell S., Jones D., Madrazo J., Martin H., Patel Y., Robinson K., Mol. Cell Biochem., 149-150, 41-49 (1995).

25) Tzivion G., Luo Z., Avruch J., Nature (London), 394, 88-92 (1998).

26) Hirasawa N., Santini F., Beaven M. A., J. Immunol., 154, 5391-5402 (1995).

27) Bonnefoy-Berard N., Liu Y. C., von Willebrand M., Sung A., Elly C., Mustelin T., Yoshida H., Ishizaka K., Altman A., Proc. Natl. Acad. Sci. U.S.A., 92, $10142-10146$ (1995). 